\title{
Fantazja, emocje, refleksja. Bajki w warsztacie nauczyciela etyki
}

\author{
Joanna Danszczyk, Magdalena Fołda, Magdalena Gilicka, Joanna \\ Gościniak, Daniel Jakubowski, Justyna Klak, Ewa Nowak, Bogumił \\ Rudawski, Aneta Tomczak (Poznań)
}

Opowieści w konwencji bajki z przesłaniem filozoficznym, ailment mogą znacząco wzbogacić warsztat nauczyciela etyki, który przymierza się do pracy z dziećmi w wieku wczesnoszkolnym. Starannie dobrana bajka, zaprezentowana przez nauczyciela (lub uczniów) w sposób sceniczny, może wzbudzić nie tylko zainteresowanie (i kluczowe w filozofii) zdziwienie (Martens, 2003), ale także tzw. dysonans poznawczy w zetknięciu z kontrowersją, dylematem lub konfliktem racji czy dóbr. Dylemat moralny jest dla ludzkiego umysłu wyzwaniem poznawczym i zadaniem do rozwiązania: efektywne uczenie, rozwój rozumienia i rozumowania moralnego, etycznego czy w ogóle społecznego potrzebują takich właśnie wyzwań. Stosując je umiejętnie, nauczyciel może stymulować rozwój umysłowy podopiecznych nie tylko od strony intelektualnej. Ponieważ celem edukacji etycznej jest nie tyle abstrakcyjna wiedza o etyce, ile rozwój praktycznej umiejętności posługiwania się zasadami, wartościami itd. we własnej refleksji, osądzie i podejmowaniu decyzji, nie wolno w procesie edukacyjnym pomijać doświadczeń i przeżyć natury afektywnej. Jean Piaget, twórca psychologii rozwoju moralnego, i Antonio Damasio, twórca neuropsychologii (także w jej aspekcie rozwojowo-edukacyjnym) są całkowicie zgodni co do ?katalitycznej? funkcji afektów w edukacji etycznej. Kluczem do rozwoju zdolności osądu moralnego, a także zdolności jego racjonalnego uprawomocnienia może być jedynie taka edukacja, która umiejętnie pobudza wrażliwość moralną i motywuje umysł do refleksji od wewnątrz. Afektywność i inteligencja rozwijają się we wzajemnej zależności: co więcej, afektywność ma tutaj wyraźny prymat, toteż w profesjonalnej edukacji etycznej należy ją stymulować wyjątkowo umiejętnie.

?Po pierwsze, afektywność może przyspieszać lub spowalniać działanie intelektu (affectivity speeds up or slows down intellectual functioning). (?) Owa przyspieszająca lub spowalniająca rola jest poza wszelką dyskusją. Uczniowie żywo czymś zainteresowani uczą się o wiele łatwiej i czerpią z uczenia więcej radości (?) Po drugie, nierozłączność inteligencji i afektywności może także oznaczać, że afektywność zmienia struktury intelektualne. A to z kolei jest źródłem nowego poznania i nowego rodzaju operacji umysłowych (source of new knowledge or new cognitive operations)? (Piaget, 1981, s. 1).

Kluczem do wspomnianego rozwoju będzie także narracja nasycona elementami emocjonalnymi (Damasio): ?jeśli opowiadacie dwie historie o podobnej długości, zawierające porównywalną liczbę faktów, i jeśli historie te różnią się tylko tym, że jedna z nich zawiera fakty nie wzbudzające emocji, a druga ? fakty wysoce emocjonujące, to słuchacze zapamiętają daleko więcej detali z opowieści nasyconej emocjonalnie aniżeli z tamtej pierwszej, emocjonalnie obojętnej? (Damasio, 1999, s. 294); do opowieści o takim działaniu z pewnością należą bajki z przesłaniem filozoficznym.

Kluczem do rozwoju będzie wreszcie wiedza, jaką nauczyciel etyki musi kierować się w swojej praktyce: że ludzkie myślenie i jego rozwój nie są i nie mogą być oderwane ?od żywego pulsu życia, od żywych pobudek, zainteresowań, skłonności człowieka myślącego (?) Kto od samego początku oderwał myślenie od afektu, ten raz na zawsze pozbawił się możliwości wyjaśnienia przyczyn myślenia, albowiem przyczynowa analiza myślenia musi zakładać wykrycie motywów myśli, potrzeb i zainteresowań, pobudek i tendencji, kierujących ruchem myśli. Kto oderwał myślenie od afektu, z góry sobie uniemożliwił także zbadanie zwrotnego wpływu myślenia na afektywny, wolicjonalny aspekt życia psychicznego? (Wygotski, 1989, s. 27-28). Aspekt wolicjonalny różni się od dowolności czy samowoli tym bardziej, im częściej stwarzamy młodym ludziom dogodne warunki zachęcające do ćwiczenia indywidualnej, wewnętrznej oceny i refleksji moralnej, im częściej zachęcamy ich do udziału w otwartej, wolnej od presji i sankcji dyskusji o tym, dlaczego i jak różne mogą być owe refleksje i oceny w świecie wielowartościowym, demokratycznym, takim jak dzisiejszy. Człowiek uczy się cenić i szanować werbalnie wyartykułowane normy w miarę, jak rozwija się jego poczucie i świadomość wartości, o jakich normy mówią wprost, albo też są w nich jakoś zakorzenione. Wykluczając afektywność z rozważań o racjonalnym samookreśleniu człowieka jako istoty moralnej, etyka podcięłaby gałąź, na której siedzi: na czym bowiem miałaby polegać ?przyczynowość pojęcia? ? tzn. Kantowski imperatyw ? jeśli nie na wpływaniu na ludzką wolę? (por. Nowak, 2002; Wygotski, 1989). Sama tylko obecność wartości wokół człowieka nie oznacza wcale, że potrafi on wartości rozpoznawać, oceniać i różnicować ich walentność, a zwłaszcza umiejętnie i konsekwentnie stosować w codziennych decyzjach i działaniach. Sprawne radzenie sobie z tymi czynnościami nie jest wyłącznie zasługą intelektu czy inteligencji: ?nasze postrzeżenia są zabarwione emocjonalnie?, podkreśla Isabel Stamm, i to właśnie sprawia, że ?otoczenie nabiera w naszym odczuciu zawsze jakiejś wartości, znaczenia. W ten sposób emocje biorą udział także w naszym myśleniu i podejmowaniu decyzji (?) Zdolność rozumnego działania, nauczenie się reguł i norm właściwego zachowania uzależnione są w poważnym stopniu od zdolności odczuwania? (Stamm, 2007, s. 109).

Dobrze skonstruowane opowieści w konwencji bajki aktywują rozwój kognicji moralnej i społecznej w tej mierze, w jakiej przedstawiają frapujące wydarzenia, w których stawką są pewne wartości i zasady natury moralnej, niewyrażone explicite, lecz obecne w przedstawionych zdarzeniach w taki sposób, że wzbudzają u słuchaczy uczucia moralne, a te z kolei (po czasie niezbędnym do przejścia od uczuć do refleksji) wyzwalają procesy świadomego rozumienia, artykulacji, refleksji, wypowiadania i 
wspólnego dyskutowania nad wartościami i zasadami, kolizjami i konfliktami natury moralnej, które zobrazowano w danej opowieści. Wykorzystując podczas 45-minutowej lekcji przynajmniej jedną do dwóch tego rodzaju opowieści, nauczyciel może skutecznie stymulować i na bieżąco obserwować rozwój wrażliwości moralnej, aktywnej refleksji i kultury dyskusji w grupie podopiecznych. Opowieści warto jednak dozować po to, by uniknąć rutyny i znudzenia, które hamują rozwój i mogłyby zniweczyć już osiągnięte efekty (sprawności umysłowe mogą się nie tylko rozwijać, ale także ulec regresji, por. Lind, 1981). Jeśli podczas semestralnego cyklu zajęć z etyki dwu- lub trzykrotnie zastosujemy bajkę o przesłaniu filozoficznym (które z reguły bywa przesłaniem etycznym), będzie to wystarczające urozmaicenie programu dydaktycznego. Opowieści tego rodzaju dają do myślenia także osobom dorosłym, co zauważyli autorzy przygotowujący przekłady bajek zamieszczonych w naszym omówieniu: warto tutaj przytoczyć powiedzenie Piageta, że ?w każdym dziecku tkwi dorosły, a w każdym dorosłym tkwi dziecko?. Wszelako, omawianie bajek w grupkach dzieci starszych niż 12-letnie może napotkać na przeszkody, ponieważ nastolatki dystansują się wobec młodszego koleżeństwa, podkreślają swoją dorosłość i mogą mogliby odebrać opowieści jako dziecinne lub ?niezbyt poważne? (Cohen 2008). Z drugiej strony, dystans ten powinnyśmy niwelować, zachęcając nauczycieli do tego, by wykorzystali tę nastoletnią ?dorosłość? w taki sposób, że poproszą nastolatków o przygotowanie bajek czy baśni dedykowanych młodszym dzieciom (ćwiczenie takie pomoże nadać ?dorosłości? jako demonstracji przewagi pewne znamiona prawdziwej dorosłości, takie jak odpowiedzialność, opiekuńczość itp.).

Opowieść utrzymana w konwencji bajki filozoficznej powinna przedstawiać konkretne rozwiązanie jakiejś kontrowersji moralnej, społecznej itp., którą dzieci poddadzą pod wspólną rozwagę, dyskretnie zachęcone i wspierane przez nauczyciela. W fazie refleksji, aby nie wyręczać dzieci, nie hamować procesu uczenia ?od wewnątrz?, nie sugerować ?jedynie słusznych? odpowiedzi i nie promować konformizmu czy chęci przypodobania się nauczycielowi taką odpowiedzią, jaką on (w przekonaniu dziecka) ?chciałby usłyszeć?, nauczyciel powstrzymuje od własnych osądów. Reprezentując etykę wolną od indoktrynacji, nauczyciel nie może rozstrzygać za nikogo o słuszności czy niesłuszności czegokolwiek. Może jednak, i zgoła powinien poddawać pod dziecięcą rozwagę otwarte pytania, sposoby uzasadniania wypowiedzi (przez podanie argumentu w odpowiedzi na pytanie ?dlaczego tak sądzisz?) itd. w jak najprostszym języku ? po to, by nikogo nie wykluczać z dyskusji i nie piętrzyć barier poznawczych (wyzwanie w postaci dylematu czy problemu do rozwiązania jest już wystarczająco duże). W ten sposób możemy ćwiczyć z dziećmi umiejętność, którą Arystoteles w Etyce Nikomachejskiej nazwał mądrością praktyczną, phronesis. Arystoteles zalecał używać jej regularnie, ponieważ cnota moralna rozwija się tylko w działaniu (tutaj: w sądzeniu i refleksji). Tę samą metodę miał na uwadze John Dewey, gdy w Demokracji i wychowaniu zalecal ?learning-by-doying? jako najbardziej skuteczną metodę edukacji moralnej i demokratycznej. Dziś potwierdzono już w setkach eksperymentów edukacyjnych, że umiejętności moralnych i społecznych - jako umiejętności z gruntu umysłowych - można i trzeba się uczyć i nauczać (Lind, 2009).

Zaproszeniem do ćwiczeń aktywujących refleksję i sądzenie mogą być jedna - dwie opowieści w konwencji bajkowej, poddające nauczycielowi pomysł na to, jak stworzyć uczniom dogodne, wolne od presji i sankcji warunki do swobodnej, otwartej dla wszystkich refleksji. Choć autorzy tego opracowania zauważyli, że bajki dają do myślenia także dorosłym, konwencja bajkowa jest najbardziej efektywna w wieku wczesnoszkolnym (od 6 do 10 roku życia). Chodzi przy tym o opowieści lub impresje niemówiące wprost o rozmaitych wartościach i zasadach potrzebnych w życiu, lecz pokazujące owe wartości i zasady w żywym działaniu, w ?grze?, w obrazowej scenie czy kolizji, tak, aby owa scena samoistnie przywiodła dzieci do wewnętrznych przeżyć i odczuć: w kolejnej fazie nauczyciel musi umiejętnie przeprowadzić dzieci od przeżycia do refleksji, rozumienia i wyrażenia tego, co przeżyły w taki sposób, jak potrafią (jeśli dzieci nie umieją nazwać zasad i wartości, to wystarczy, że posłużą się przykładami. Uczestnicy dyskusji powinni mieć po prostu odczucie, że wiedzą, o czym mowa).

Opowieści w konwencji bajkowej powinny klarownie przedstawiać wydarzenia bliskie doświadczeniom z dziecięcego życia, bez nadmiernych udziwnień i abstrakcji, odciągających uwagę od problemu moralnego. Dobierając opowieść i opracowując ją językowo, nauczyciel musi się zdecydować, czy chce uczyć wszystkich możliwych rzeczy na raz (retoryki, estetyki, opisów przyrody itd.), czy też woli solidnie przećwiczyć określone rozumowanie moralne. Opowieść nie może być przy tym nudna i banalna: powinna angażować emocjonalnie, być wyzwaniem dla rozumienia i zaproszeniem do refleksji. W każdej grupie dana opowieść i rozmowa mogą przebiegać inaczej i przynieść odmienne, zaskakujące efekty: nauczyciel musi być na te odmienności przygotowany i wiedzieć, że ćwiczenie namysłu etycznego i filozoficznego zakłada jako warunek właśnie różnorodność odczuć, perspektyw, opinii. Różnorodność jest wszechobecna w życiu i musimy sobie z nią radzić, toteż popadlibyśmy w edukacyjną fikcję i stali niewiarygodni w oczach uczniów, gdybyśmy ją sztucznie eliminowali z klasowej społeczności. Zniweczylibyśmy też długofalowy efekt dydaktyczny, poprawiając, komentując i oceniając dziecięce wypowiedzi: bowiem wspólne zapytywanie i badanie jako klasyczna, sokratejska podstawa refleksji etycznej (do podstawy tej zaliczają się tzw. pytania generatywne towarzyszące opowieściom i stymulujące do refleksji) prowadzą dyskutantów do samodzielnej korekty własnych wypowiedzi. Autokorekta zaś (?self-correcting?) (Camhy, 2007, s. 231) jest skuteczna tylko jako autokorekta, jako proces wewnętrzny i samodzielny, stymulowany jedynie przez wypowiedzi innych dyskutantów, które przekonały ?mnie? siłą swojej rozumności ? nigdy zaś siłą perswazji, przymusu czy autorytet jako ?ciał obcych? względem rozumu (Habermas, 1983). Włączając do dyskusji, akceptując i wspierając wszystkie dzieci na równi, nauczyciel oferuje im oprócz możliwości autokorekty tak dogodne warunki, że dzieci w niewymuszony sposób stają się wspólnotą badawczą (?community of inquiry?) (Sharp, 2007, s. 87), rozmawiając z pasją i wzajemnym szacunkiem ponad wszelkimi różnicami o tym, co się ? ich zdaniem - w danej opowieści zdarzyło, tym, co się zdarzyć powinno lub nie powinno itd.

Pytania o różnicę między tym co jest, a tym, co być powinno mają charakter normatywny, stricte etyczny. Jak formułować pytania generatywne, pokazaliśmy to na przykładzie pytań towarzyszących kilku opowieściom przytoczonym niżej. Zwróćmy 
uwagę, że wszystkie słowa typu: czy można, czy powinno się, czy nie powinno, czy warto, jak się czuje ktoś? itd. zachęcają do samodzielnego osądu. Pamiętajmy przy tym, że takt wymaga od nauczyciela, aby powstrzymał się od komentowania dziecięcych osądów; wyręczy go w tym opisana wyżej zasada autokorekty. Po jakimś czasie dzieci same poprawią swoje osądy i ich uzasadnienie. Dla nauczyciela etyki będzie to największy sukces dydaktyczny.

Sama dyskusja, prowadząc do wzajemnego zrozumienia lub (niekoniecznie) porozumienia może procentować w dziecięcym zachowaniu tak silnie, że z czasem poprawi atmosferę w grupie, podniesie komfort współpracy nauczyciela z podopiecznymi i wpłynie na całkowity efekt nauczania. O tym, jak ogromny potencjał ma dziecięca refleksja moralna można się przekonać dopiero wówczas, gdy samemu przeprowadzi się kilka prostych ćwiczeń, prosząc asystenta o protokołowanie (w skrócie) wszystkich dziecięcych wypowiedzi na tablicy. Zaproszenie do namysłu, stworzenie atmosfery zaufania, pełne włączenie wszystkich uczniów do rozmowy wymagają jednak od nauczyciela dobrego przygotowania i zdecydowanego przeciwstawienia rutynowym szkolnym praktykom. Na lekcji etyki nie sposób myśleć i rozmawiać w pośpiechu, pod dyktando i pod groźbą sankcji.

Poniżej przytaczamy wybrane przykłady i przekłady opowieści z przesłaniem etycznym (ale bez jednoznacznego, banalnego ?morału?). Są to efekty wspólnego ćwiczenia, które sprawiło autorom wiele radości i przyniosło ważne doświadczenie: umiejętność samodzielnego doboru i aranżowania dobrych materiałów dydaktycznych. Opowieści opatrzyliśmy pytaniami generatywnymi, mającymi aktywować i orientować refleksję w określonym kierunku, tak, aby nauczyciel mógł rzeczywiście przeprowadzić dyskusję i kontrolować jej przebieg. Może stawiać kolejno po jednym pytaniu, dając każdemu szansę wypowiedzenia się, a przede wszystkim czas do namysłu (i ewentualnie notatek, które w ciągu kilku minut po prezentacji mogą sobie przygotować uczniowie). Po zakończeniu prezentacji przeżycia wzbudzone przez opowieść mogą być tak silne, że uczniowie będą potrzebowali kilku minut, aby zebrać i wyartykułować myśli. Nauczyciel musi im zapewnić jak najwięcej czasu.

Oprócz jednej, wszystkie opowieści zaczerpnęliśmy z niemieckiej edycji książki Michela Piquemala (z ilustracjami P. Laguatriere?a) pt. ?Philo fabelhaft? (oryginalna wersja francuska: ?Les philo-fables?). Jedna opowieść przełożona została z języka rosyjskiego (źródło: ?Skazki narodow...?, Warszawa 1981). Traktujemy opracowane na nowo bajki jako promocję książki w etyce edukacyjnej i przytaczamy je tutaj w charakterze cytowań dydaktycznych.

\section{Słowo}

?Pewnego dnia rybak, który właśnie rozrzucił swoją sieć, znalazł na plaży wysuszoną czaszkę. Dla żartu zapytał ją: ?Powiedz mi, co cię tu sprowadza??. Jakże był zaskoczony, gdy czaszka odpowiedziała mu: ?Słowo!?.

Rybak pobiegł natychmiast do miasta, wpadł do pałacu królewskiego i opowiedział królowi, co mu się przydarzyło. ?Co takiego?? zdziwił się król. ?Gadająca czaszka?? ?Lepiej uważaj?, pogroził król palcem, ?bo jeśli mnie okłamałeś, to wiedz, twoja własna głowa już dość długo tkwi na karku. Uważaj na nią.?

Król udał się z całym orszakiem na plażę, by przekonać się o cudzie na własne oczy. Wtedy rybak podszedł do czaszki i powtórzył swoje pytanie: ?Czaszko, powiedz, co cię tu sprowadza??

Ale tym razem nie zdarzyło się nic. Czaszka nie odpowiedziała.

Król dobył swojej szabli i ściął biednemu rybakowi głowę. Odwrócił się i poszedł z powrotem do pałacu.

Ledwie król zniknął, czaszka zwróciła się do ściętej głowy rybaka i zapytała ją: ?Proszę, powiedz mi, co ciebie tutaj sprowadziło??. ?Słowo?, odrzekła głowa rybaka.?

(przeł. B. Rudawski, bajka afrykańska: Piquemal \& Lagautriere 2003-2004, s. 50-51)

Runda filozoficzna:

Pytania generatywne zamieszczone w wersjach: niemieckiej, francuskiej i polskiej: ?Gadulstwo i rozpowiadanie kosztowały tego mężczyznę głowę. Oczywiście taka cena jest mocna przesadzona. Jak we wszystkich bajkach, chodzi tutaj tylko o przesłanie symboliczne: może warto pomyśleć, zanim otworzy się usta i zacznie mówić?

A jaką naukę Ty wyciągnąłbyś z tej historii? Kiedy powinniśmy mówić, a kiedy lepiej byłoby milczeć? Czy widać tu jakieś podobieństwa z opowieścią o Sokratesie i jego trzech sitach?? (tamże, s. 51)

Pytania generatywne z dziedziny etyki:

Czy zawsze powinno się wierzyć w to, co usłyszało się od innej osoby, a nawet wielu osób, i samemu nie sprawdziło, czy to prawda?

Czym się różni wiara od wiedzy? Skąd mamy pewność, że coś wiemy? Czy można wiedzieć o tym, że się czegoś nie wie?

(klasyczne pytanie Sokratejskie).

Skąd wiadomo, że ktoś mówi prawdę?

Czy można każdemu powiedzieć wszystko?

(Tę opowieść można prezentować w jednym ?cyklu? z opowieścią o Sokratesowym ?potrójnym sicie?, która jeszcze silniej wydobywa pytania o prawdziwość, pożytek i dobrodziejstwa płynące z mowy i rozmowy. Pytania o pewność i prawdziwość należą do teorii poznania, czyli epistemologii).

\section{Zajęcza dola}


?Pewnego dnia zające miały już serdecznie dość swojego losu: bo co to za życie, stale drżeć i uciekać przed wrogiem? Zwołały wielkie zgromadzenie. „Przecież to nie jest życie!”, skarżyły się. „Żaden inny gatunek nie lęka się tak jak my. Najlżejszy podmuch wiatru czy opadający liść sprawiają, że trzęsiemy się i rzucamy do ucieczki. Strach nie opuszcza nas ani na chwilę. Nie ma stworzeń bardziej od nas żałosnych. Lepiej od razu umrzeć niż żyć tak dalej!? Zające uchwaliły uroczyście, że na drugi dzień cały zajęczy ród skoczy do rzeki. Gdy nastał nowy dzień, ruszyły ku rzece. Ale gdy tylko dotarły na brzeg, tupot wielu zajęczych łapek przestraszył roje żab, które grzały się dotąd w słońcu. Żaby wskakiwały do wody jak oparzone. Wtedy zające ujrzały, że są na świecie zwierzaki jeszcze bardziej strachliwe od nich. Nagle życie wydało im się znowu piękne! I zamiast się utopić, pokicały beztrosko dalej, ku zielonym trawom, smacznym ziołom i soczystym łąkom.?

(przeł. E. Nowak, opowieść z Anatolii, dzisiejsza Turcja: Piquemal \& Laguatriere, 2003-2004, s. 108-109)

\section{Runda filozoficzna:}

Pytania generatywne zamieszczone w wersji niemieckiej, francuskiej i polskiej: ?Kiedy jesteśmy nieszczęśliwi, to wydaje nam się, że już nikt nie jest bardziej nieszczęśliwy od nas. Warto się jednak rozejrzeć dookoła, bo najczęściej dookoła są ludzie, których spotkało jeszcze większe nieszczęście.

Czy sądzisz, że to właściwe, pocieszać się w ten sposób (że porównujemy się z innymi ? uzup. autorów)? Jeśli nie, to skąd czerpać siłę potrzebną do przezwyciężenia takich ciężkich sytuacji? Skąd się bierze ta siła??

(tamże, s. 109).

\section{Pytania generatywne z dziedziny etyki:}

Czy lęk jest zawsze zły? (kiedy nie jest? Np. kiedy ostrzega nas przed prawdziwym niebezpieczeństwem)?

Czy oswoić strach to znaczy stracić wrażliwość, stać się nieczułym? Lepiej być wrażliwym czy nieczułym? (pytanie ?stoickie?, nauczyciel zachęca do swobodnego podawania przykładów, a dodatkowymi pytaniami zaprasza do bardziej ogólnych refleksji w rodzaju: Czy to naprawdę dobrze, nie bać się niczego? A może lęk też jest potrzebny, tak samo jak inne uczucia?)

Co to za siła czy energia, która pozwala zapanować nad strachem? Może to jest myślenie?

Skąd się biorą w życiu odwaga i wiara w we własne siły?

Wyobraź sobie, że twój bliski przyjaciel czy koleżanka bardzo się czegoś boją. Jak byś im pomógł, masz jakiś pomysł?

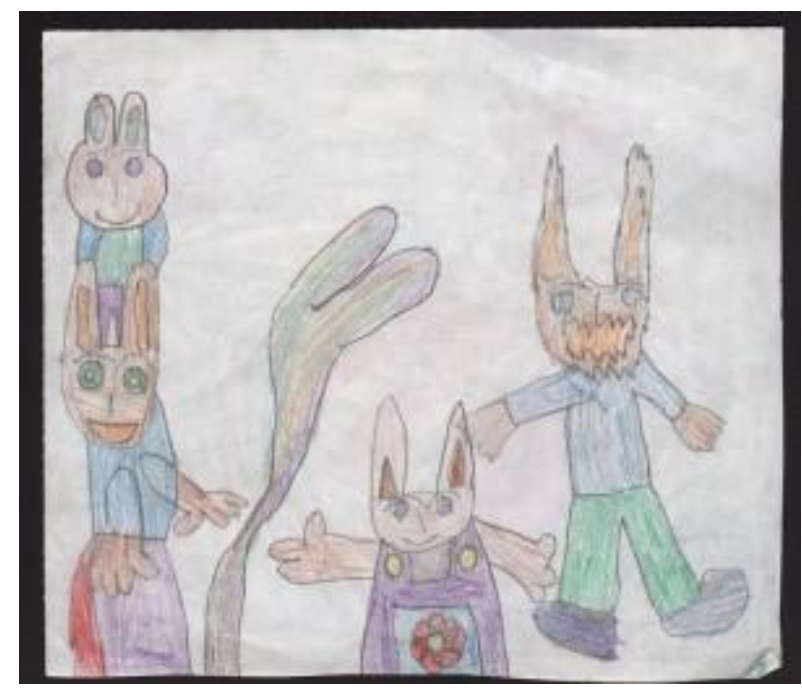

Zające (Gardenia, lat 5)

\section{Jeże}

?Pewnego zimowego dnia chwycił taki mróz, że kolczaste zwierzątka zwane jeżami nie mogły już wytrzymać z zimna. Przytuliły się jedno do drugiego, żeby nie zamarznąć. Wtedy poczuły, że coś je gryzie i kłuje. Obolałe zwierzaki rozstąpiły się i oddaliły trochę od siebie, ale wtedy znów zaczęły marznąć. Mróz trzymał, nie było wyboru. Trzeba się było znowu przytulić do siebie. I ponownie podniósł się płacz i pisk wśród jeży: wszystkich kłuło już z każdej strony. Jeże próbowały i próbowały: jaka odległość będzie najbezpieczniejsza, żeby się nawzajem ogrzać, a zarazem nie pokłuć? Wreszcie znalazły taką odległość. Było im teraz dosyć ciepło, i nikogo już nic nie bolało.?

(przeł. J. Danszczyk \& J. Gościniak, bajka opowiadana przez A. Schopenhauera: Piquemal \& Laguatriere, 2003-2004, s. 10)

\section{Runda filozoficzna:}

Pytania generatywne umieszczone w wersji niemieckiej, francuskiej i polskiej: ?Ludzie także potrzebują pewnego odstępu czy też wzajemnego dystansu. Uprzejmość i takt pomagają nam uszanować tę potrzebę u innych osób. Z człowiekiem jest właśnie tak, że 
z jednej strony potrzebuje innych, a z drugiej ? potrzebuje niezależności. Pomyśl, czy przeszkadza ci to, że twój najlepszy przyjaciel czy też najlepsza przyjaciółka wycofują się czasem do świata, który jest dla ciebie niedostępny??

(tamże, s. 10)

Pytania generatywne z dziedziny etyki:

Jakie to uczucie, kiedy inne osoby zawsze kontrolują, co robimy?

Czy nie można komuś zaufać bez sprawdzania i obserwowania go przez cały czas?

Czy są w twoim życiu sytuacje, że wolał(a)byś być sam(a)?

Czy warto chronić ludzkie prawo do prywatności? Jak dać innym do zrozumienia, że potrzebujemy prywatności, czy to łatwe?

Co to jest takt? Co to jest szacunek? (w każdym wypadku nauczyciel wydobywa różnorodne wypowiedzi i zachęca do swobodnego wypowiadania się zwłaszcza te osoby, które dotąd nie zabrały głosu ? chodzi o zachętę, a nie o presję i sankcje).

Co jest ważne: nasze własne dobro i potrzeba czy może dobro i potrzeby ludzi w ogóle?

(Komentarz dla nauczyciela: chodzi o klasyczne pytanie etyki i filozofii społecznej: ?jednostka czy wspólnota?? A może jedno i drugie?)

\section{IV. Żaba i skorpion}

?Pewnego razu na brzegu rzeki siedział skorpion. Chciał przedostać się na drugą stronę. Dlatego zwrócił się do żaby: ?Proszę, weź mnie na swój grzbiet i pomóż mi dostać się na drugi brzeg?.

?Życie mi jeszcze miłe?, odrzekła na to żaba. ?Jeśli cię wezmę na swój grzbiet, to mnie ukąsisz i umrę!?,

?Nie bądź głupia?, odpowiedział żabie skorpion. ?Czemu miałbym cię ukąsić? Jeśli cię ukąszę, to oboje utoniemy. Przecież wiesz, że nie umiem pływać.?

Wreszcie po długich namowach żaba dała się przekonać. Wzięła skorpiona na swój grzbiet i wskoczyła do wody. Ale gdy upłynęli kilka metrów, poczuła nagle piekący ból w plecach. Trucizna szybko paraliżowała jej ciało. ?No i zobacz skorpionie, ukłułeś mnie!?, wykrzyknęła żaba. ?Przez ciebie teraz umrę!? Na to skorpion: ?Wiem, przykro mi? Ale taka jest moja natura.? I razem utonęli w szlamie.?

(przeł. M. Fołda \& M. Gilicka, bajka afrykańska: Piquemal \& Laguatriere 2003-2004, s. 16-17)

\section{Runda filozoficzna:}

Pytania generatywne zamieszczone w wersji niemieckiej, francuskiej i polskiej: ?Takie są prawa natury. Skorpion zabija swoje ofiary przez ukąszenie, a antylopy zostają pożarte przez lwy. A czy wśród ludzi obowiązują takie same zasady, jak w świecie zwierząt? Czy jesteśmy całkowicie zdani na nasze ludzkie instynkty? Jak możemy je poskromić, kontrolować, czy nawet nad nimi zapanować?

Czy masz czasem uczucie, że twój instynkt działa wbrew twojemu sumieniu albo wbrew twojej woli?? (tamże, s. 17).

Pytania generatywne z dziedziny etyki:

Czy do tego, żeby komuś pomóc, potrzebne jest zaufanie? (nauczyciel wydobywa mozliwe różne wypowiedzi, nie ocenia odpowiedzi, zachęca uczniów, by wymienili między sobą różne odpowiedzi, by wypowiedział się każdy)

Czy nie powinno się pomagać innym, jeśli wiąże się to z niebezpieczeństwem i ryzykiem? Czy można to wiedzieć od początku? Co by było, gdyby nikt nie ryzykował? Jak wyglądałoby wtedy nasze życie? (nauczyciel zachęca uczniów do orwartej wymiany możliwie różnych opinii itd., j.w.)

\section{Mędrzec}

Dawno temu żył sobie starzec, który miał wielu synów. Pewnego dnia zwołał ich wszystkich, wręczył jednemu z nich strzałę i powiedział: ?Przełam ją na pół i daj bratu.? Syn złamał strzałę i dał kawałki bratu. Ten złożył je razem, przełamał na czworo i podał części trzeciemu bratu. Gdy trzeci brat spróbował przełamać je dalej, napotkał opór: ?Ojcze, nie mam tyle siły, żeby je złamać!? Wtedy starzec wstał i powiedział:

?Synowie moi, ta strzała jest podobna do was. Jeśli będzie żyli sami, w pojedynkę, to każdy was złamie. Ale jeśli będziecie żyli razem i w zgodzie, to nie złamie was żadna siła i spędzicie życie w radości i szczęściu.?

(przeł. J. Klak-Nowakowa, bajka uzbecka: ?Skazki narodow?, 1981, s. 36-37)

Pytania generatywne z dziedziny etyki:

Czy lepiej jest żyć samemu i móc liczyć tylko na siebie, czy też trzymać się razem z innymi?

Dlaczego ludzie niechętnie żyją samotnie, po co zakładają rodziny, mieszkają we wspólnych domach, miastach itd.?

Czy w pojedynkę można osiągnąć więcej niż z innymi?

Co to jest solidarność?

Przyjaźń?

Wspólnota? (nauczyciel stara się zachęcić uczestników do wskazania zarówno plusów, jak i minusów życia w samotności i we wspólnocie, wzmacniając myślenie krytyczne). 


\section{Potrójne sito Sokratesa}

Któregoś dnia pewien mężczyzna udał się do filozofa Sokratesa i powiedział do niego: ?Słuchaj Sokratesie, muszę ci koniecznie coś opowiedzieć o zachowaniu twoich przyjaciół?.

?Czekaj ? odparował Sokrates - muszę ci od razu przerwać. Czy pomyślałeś o tym, żeby to, co masz zamiar mi powiedzieć, przesiać wcześniej przez potrójne sito??

A ponieważ mężczyzna patrzył na filozofa nie rozumiejąc, o czym mowa, Sokrates ciągnął dalej: ?Tak, tak. Bo zanim otworzysz usta, powinienneś najpierw przesiać twoje myśli przez potrójne sito. Posłuchaj mnie dobrze! Pierwsze sito to Prawda. Czy sprawdziłeś, że to, co chcesz mi opowiadać, też jest całkiem prawdziwe??

?Hm? nie sprawdziłem. Gdzieś tylko o tym słyszałem??

?Ach tak! Zakładam więc, że przesiałeś twoje słowa przynajmniej przez sito Dobroci. Czy to, co chciałbyś mi powiedzieć, to coś dobrego ??

Mężczyzna odpowiedział z ociąganiem: ?Eh? niestety nie. Wręcz przeciwnie?.

?Aha! - zawołał filozof ? więc przejdźmy teraz do trzeciego sita. Czy w tym, co chciałbyś mi opowiedzieć, jest w ogóle jakiś Pożytek??

?Pożytek?? Niekoniecznie.?

?Więc lepiej nie mówmy już o tym!?, powiedział Sokrates, ?Bo jeśli to, co chcesz mi powiedzieć, nie jest ani prawdziwe, ani dobre, i na dodatek nie ma w tym żadnego pożytku, to wolę o tym nie wiedzieć. A i tobie radzę o tym zapomnieć, i to najlepiej od razu.?

(przeł. D. Jakubowski, przypowieść podawana za Sokratesem, 470-399 p.n.e., Piquemal \& Laguatriere, 2003-2004, s. 42-43)

\section{Runda filozoficzna:}

Pytania generatywne zamieszczone w wersji niemieckiej, francuskiej i polskiej: ?Czasem zdarza się, że nie umiemy się powstrzymać od opowiadania rzeczy, które gdzieś od kogoś zasłyszeliśmy. Ale czy nie jest to trochę niebezpieczne, powtarzać niesprawdzone wieści i plotki innym? Dlaczego właściwie, jak uważasz? Co sądzisz o trzech sitach?? (tamże, s. 43)

Pytania generatywne z dziedziny etyki:

Jak sądzisz, czy Sokrates miał rację? Czy te trzy sita mogą się do czegoś przydać?

Co to znaczy: ?pomyśl dwa razy, zanim powiesz głośno???

Co jest lepsze, prawda czy kłamstwo? Dlaczego?

Czy ważne jest dla człowieka, żeby mówić prawdę?

Skąd wiemy, że coś jest lub nie jest prawdziwe?

Jak się czujemy, kiedy ktoś nam opowiada o rzeczach nieprawdziwych?

Jak wyglądałoby nasze życie, gdyby wszyscy kłamali lub opowiadali coś bez zastanowienia?

\section{Pierścień Gygesa}

Dawno, dawno temu grecki pasterz Gyges zobaczył u zmarłego człowieka tajemniczy pierścień. Zdjął go, założył na swój palec i nosił odtąd dzień i noc. Pewnego król wezwał do siebie pasterzy. I gdy tak stali przed królem, Gyges bez namysłu obracał pierścień na swoim palcu. Po chwili uświadomił sobie, że stał się niewidzialny! Inni pasterze opowiadali o nim bowiem tak, jakby Gygesa na zgromadzeniu nie było. było wśród zgromadzonych. Gdy Gyges przekręcił pierścień, znowu stał się widzialny. Pierścień miał dziwną moc. W głowie Gygesa zaczęły krążyć mroczne myśli. Pozazdrościł królowi bogactwa. A skoro mógł skorzystać z niewidzialności, postanowił wrócić do pałacu, uwieść królową, zabić króla i wreszcie samemu wstąpić na tron.

(przeł. A. Tomczak: opowieść zaczerpnięta z Platońskiego „Państwa? (427-347 pne), Piquemal \& Lagautriere, s. 76-77)

\section{Runda filozoficzna:}

?W opowieści tej filozof Platon zawarł następujące pytanie: ?Gdybyśmy posiedli pierścień Gygesa i byli bezkarni, to czy nie wstydzilibyśmy się wtedy kraść, zabijać i robić co nam się żywnie podoba?

Mówiąc innaczej: dlaczego włąściwie wystrzegamy się robienia złych rzeczy? Czy dlatego, że wiemy, że nie należy tak postępować, czy może dlatego, że obawiamy się kary?? (tamże, s. 77).

Dalsze pytania generatywne z dziedziny etyki:

Jak sądzisz, dlaczego ludzie, którym zdarza się zrobić coś niewłaściwego, starają się to ukryć przed innymi? (Komentarz dla nauczyciela: chodzi o Kantowskie pytanie, dlaczego ludzie czyniąc dla siebie ?wyjątek? od jakiejś reguły powszechnej starają się, aby nikt inny o tym nie wiedział).

Czy jeśli nikt inny nie wie, co robimy, to możemy robić wszystko co nam się podoba?

Czy jeśli inni nie wiedzą, co robimy, to jest nam łatwiej o tym zapomnieć?

Czy jeśli nie grozi nam żadna kara, to wolno robić wszystko? (Komentarz dla nauczyciela: chodzi o pytanie w duchu Dostojewskiego: ?jeśli piekła nie ma, to czy wszystko jest dozwolone??)

\section{Literatura}


Camhy, D. G. (2007). Philosophical dialogue as foundation of innovative learning. W: D. G. Camhy (Ed.), Philosophical foundations of innovative learning. Proceedings oft the International Conference on Philosophy for Children. Sankt Augustin: Akademia Verlag, ss. 230-237.

Cohen, M. (2008). Philosophical tales. New Jersey: John Wiley Blackwell Publishing.

Damasio, A. (1999). The feeling of what happens. New York: Harcourt Bracer \& Co.

Habermas, J. (1981, 2010). Philosophical notes on Moral Judgment Theory. W: G. Lind, H.A. Hartmann, \& R. Wakenhut (Eds.), Moral Judgments and social education. 2nd Edition. New Brunswick \& London 2010: Transaction Publishers, ss. 3-20.

Habermas, J. (1983). Moralbewusstsein und kommunikatives Handeln. Frankfurt/M.: Suhrkamp.

Lind, G. (2002, 2009). Moral list lehrbar. München: Oldenbourg.

Nowak, E. (2002). Autonomia jako zasada etyczności. Kant, Fichte, Hegel. Wrocław: WUWr.

Piaget, J. (1981). Intelligence and affectivity. Trans. T.A. Brown \& C.E: Kaegi. Palo Alto: Annual Reviews, Inc.

Piquemal, M. \& Laguatriere, Ph. (2003). Les philo-fables. Paris: Albin Michel.

Piquemal, M. \& Laguatriere, Ph. (2004). Philo fabelhaft. 63 Fabeln aus aller Welt und ihre philosophische Bedeutung. Kempen: Moses Verlag.

Piquemal, M. (2004). Bajki filozoficzne. Warszawa: Wydawnictwo Muchomor.

Sharp, A. M. (2007). The classroom community of inquiry and the education of emotions. W: D. G. Camhy (Ed.), Philosophical foundations of innovative learning. Proceedings oft the International Conference on Philosophy for Children. Sankt Augustin: Akademia Verlag, ss. 84-94.

Stamm, I. (2007). Zwischen Neurobiologie und Sozialethik. Oldenbourg: BIS-Verlag der Universität Oldenbourg.

Wygotski, L. (1989). Myślenie i mowa. Warszawa: PWN. 